\title{
Banana (Musa paradisiaca) Midrib Extract as a Curative Agent of Motile Aeromonad Septicemia in Giant Gourami (Osphronemus gouramy)
}

\author{
Dinamella Wahjuningrum ${ }^{1} \mathbb{D}$, Ike Dewi Nur Fitrianingrum ${ }^{1}$, Widanarni Widanarni $^{1 *}$ \\ , Diah Ayu Satyari Utami ${ }^{2}$
}

${ }^{1}$ IPB University, Faculty of Fisheries and Marine Science, Department of Aquaculture, Bogor 16680, Indonesia

${ }^{2}$ Marine and Fisheries Polytechnic of Jembrana, Department of Aquaculture, Jembrana 82218, Indonesia.

\begin{abstract}
How to cite
Wahjuningrum, D., Fitrianingrum, I.D.N., Widanarni, W., Utami. D.A.S. (2021). Banana (Musa paradisiaca) Midrib Extract as a Curative Agent of Motile Aeromonad Septicemia in Giant Gourami (Osphronemus gouramy). Turkish Journal of Fisheries and Aquatic Sciences, $21,589-602$. http://doi.org/10.4194/1303-2712-v21_12_02
\end{abstract}

\section{Article History}

Received 26 March 2021

Accepted 04 August 2021

First Online 11 August 2021

Corresponding Author

Tel.: +628129357404

E-mail: widanarni@yahoo.com

\section{Keywords}

Aeromonas hydrophila

Antibacterial

Flavonoid

Leukocyte

\begin{abstract}
This study aimed to evaluate the effects of banana (Musa paradisiaca) midrib extract supplementation as preventive and curative treatments of motile aeromonad septicemia (MAS) on giant gourami (Osphronemus gouramy). Disc diffusion assay was conducted to evaluate antibacterial activity of banana midrib extract against Aeromonas hydrophila. The most effective dose was used for subsequent tests. Experimental fish were categorized into five groups: negative control; positive control; and preventive, curative, and controlling treatments. Except negative control, all groups were challenged by $A$. hydrophila at a density of $10^{7} \mathrm{CFU} \mathrm{mL}-1$ ( $0.1 \mathrm{~mL}$ per fish). Preventive, curative, and controlling treatment groups were administered the banana midrib extract-enriched diet (3\%), whereas positive and negative controls were not treated with banana midrib extract. The results showed that banana midrib extract inhibited $A$. hydrophila activity in giant gourami, demonstrated by lower $A$. hydrophila numbers in preventive, curative, and controlling treatments than those in the positive control. After the challenge test in the fish treated with banana midrib extract, immunity parameters were better than those of the positive control. Banana midrib extract was highly effective as a curative agent against MAS in giant gourami based on the highest survival of the experimental fish compared with other treatments.
\end{abstract}

\section{Introduction}

Giant gourami (Osphronemus gouramy) belongs to the phylum Chordata, class Actinopterygii, order Perciformes, and family Osphronemidae. Giant gourami is an economically important freshwater commodity and a popular indigenous species in Indonesia. It is widely cultured in Java and Sumatera (Welcomme, 1988; Setijaningsih et al., 2007; Azrita \& Syandri, 2015). The production of giant gourami has expanded in Sulawesi, Kalimantan, Bali, Nusa Tenggara, Maluku, and
Papua owing to its high market demand (Sukenda et al., 2020). This species has specific characteristics, including air-breathing capability and solid vegetarian diet component (Slembrouck et al., 2019), thereby lowering feeding costs (Kristanto et al., 2020). The high demand for this species triggers intensive culture system practices that affect the aquaculture environment and cause a deterioration in fish health through increased disease outbreak incidents (Koesharyani \& Gardenia, 2013; Gardenia et al., 2020). The common bacterial species that attack giant gourami are Streptococcus 
iniae, Streptococcus agalactiae, Nocardia sp., Aeromonas hydrophila, Aeromonas caviae, Staphylococcus saprophyticus, Flavobacterium sp., and Mycobacterium fortuitum (Kitao et al., 1989; Lusiastuti et al., 2008; Purwaningsih \& Taukhid, 2010; Minaka et al., 2012).

Motile aeromonad septicemia (MAS) is a disease caused by $A$. hydrophila, a Gram-negative, oxidasepositive, facultative anaerobic, and opportunistic aquatic pathogen that produces the following virulence factors: hemolysin, aerolysin, adhesin, enterotoxin, phospholipase, and lipase. This mesophilic species attacks some freshwater fish species, such as carp (Cyprinus carpio), tilapia (Oreochromis sp.), catfish (Clarias sp.), blue gourami (Trichogaster trichopterus), and giant gourami (Ismail et al., 2010; Janda \& Abbott, 2010; Stratev \& Odeyemi, 2016). MAS occurs as an acute, chronic, or latent infection. Disease incidence suppresses the immune response, thereby enhancing infection susceptibility at an alarming rate associated with significant fish mortality, resulting in enormous economic losses (Ibrahem et al., 2008; Ismail et al., 2010).

The incidence of fish diseases can be addressed by controlling the infection through correct and effective preventive or curative treatments. The use of antibiotics has not been recently recommended in commercial aquaculture owing to their residual effects on cultured species, their impacts on the development of resistant bacteria, and the destruction of the bacterial population in the cultivated aquatic environment (Kahuripan et al., 2009). Several previous investigations revealed the emergence of multidrug-resistant bacterial pathogens from different origins, especially fish, thereby increasing the need for new natural antimicrobial alternatives to the commonly used old antimicrobial agents (Abouelmaatti et al., 2013; Enany et al., 2018; El-Sayed et al., 2019; Abolghait et al., 2020; Algammal et al., 2020a; Algammal et al., 2020b; Algammal et al., 2020c; Algammal et al., 2020d; Algammal et al., 2020e). Plant extracts are now notably gaining attention as natural immunostimulants and antimicrobials to replace antibiotics (Hardi et al., 2019). These natural plant origin products such as vegetables, herbs, spices, edible plants, and their extracts act as growth promoters, immunostimulants, and antistress, antioxidant, or antimicrobial agents with no detrimental impact on the environment and no residual effects to the cultured fish (Galindo-Villegas \& Hosokawa, 2004; Citarasu, 2010). Extracts of several plants such as Indian almond leaves, oats, oyster mushrooms, nettle, seagrass, and beetroot have been utilized to replace antibiotics (Baba et al., 2016; Bilen et al., 2016; Devi et al., 2016; Nugroho et al., 2017). One of the promising phytopharmaceutical products is banana (Musa paradisiaca) midrib. It was considered because of its abundance and it is generally discarded as waste material. Banana midrib contains antioxidant and phytochemical materials. Antioxidant materials in banana midrib include ascorbic acid, $\beta$ carotene, and lycopene, and the phytochemical materials include flavonoid, tannin, saponin, and alkaloid (Apriasari et al., 2014). The percentage of flavonoid content in banana midrib was higher (28.10\%) compared with those in papaya $(0.0012 \%)$ and guava (0.0018\%) leaves (Miean \& Mohamed, 2001). The efficacy of banana midrib has been tested to prevent $A$. hydrophila infection in giant gourami through immersion, indicating positive results (Fitrianingrum, 2014). However, another use of banana midrib in aquaculture, particularly as a controlling agent of fish diseases, has not been widely reported. This study aimed to evaluate the effects of the supplementation of banana midrib extract as preventive and curative treatments of MAS on giant gourami by observing infection rate, blood profile, and immune responses.

\section{Materials and Methods}

\section{Preparation of Banana Midrib Extract}

Banana midrib extract was prepared following a method described by Sakunphueak and Panichayupakaranant (2010) and Giri et al. (2016). First, the banana midrib was chopped into some small pieces of $2 \mathrm{~cm}$. Next, these pieces were dried in an oven set at $45^{\circ} \mathrm{C}$. The material was then milled using a milling machine to obtain banana midrib powder.

Banana midrib powder ( $25 \mathrm{~g}$ ) was mixed with 100 $\mathrm{mL}$ methanol. The mixture was then homogenized using a magnetic stirrer for $3 \mathrm{~h}$ to obtain the mixture deposit. The deposit was condensed for $24 \mathrm{~h}$ to obtain a filtrate and a pulp. Pulp (100 mg) was mixed with $20 \mathrm{~mL}$ methanol, homogenized for $1 \mathrm{~h}$ to obtain a filtrate, and evaporated using a rotary evaporator to produce a thick banana midrib extract.

\section{Preparation of Bacterial Stocks}

Pathogenic bacteria used in this study were $A$. hydrophila and Streptococcus agalactiae NK1. The isolate of $A$. hydrophila was a collection of the Fish Health Laboratory, Department of Aquaculture, Faculty of Fisheries and Marine Science, IPB University, Bogor, West Java, Indonesia. This bacterial isolate was obtained from kidneys of an infected catfish. Moreover, the isolate of $S$. agalactiae NK1 was a collection of the Center of Freshwater Aquaculture Research, Bogor, West Java, Indonesia. This bacterial isolate was obtained from the brain of an infected tilapia. The stocks of $A$. hydrophila were cultured on trypticase soy agar (TSA), whereas those of $S$. agalactiae NK1 were grown on brain heart infusion agar (BHIA). The bacterial stocks were identified through Gram staining as well as physiological and biochemical tests, including oxidative/fermentative, motility, oxidase, and catalase tests. Moreover, the used bacterial isolates were re-identified using the API 20E kit and API 20 Strep kit (bioMérieux, Inc., North Carolina, USA). The results of bacterial identification indicated 
that the bacterial stocks were $A$. hydrophila and $S$. agalactiae NK1 based on the characteristics described in Bergey's Manual of Determinative Bacteriology (Holt et al., 1994) as presented in Table 1.

\section{Phytochemical Screening and Antimicrobial Activity Test of Banana Midrib Extract}

The banana midrib extract was separately screened for the presence of bioactive compounds, including flavonoid, tannin (Trease \& Evans, 2002), alkaloid, triterpenoid, saponin, steroid (Sofowora, 1993), phenolic, and glycoside (Roghini \& Vijayalakshmi, 2018). This step was followed by the quantification of phytochemical contents in banana midrib extract using the procedures demonstrated by Venkatesh et al. (2014).

The antimicrobial activity of banana midrib extract was measured using the disc diffusion assay described by Hudzicki (2009) and CLSI (2018) with a modification. Disc diffusion assay was performed by spreading the suspension of $A$. hydrophila onto the TSA plate and that of $S$. agalactiae NK1 onto the BHIA plate. Next, sterile paper discs with a diameter of $0.5 \mathrm{~cm}$ were immersed in various banana midrib extract solvents $(1 \%, 2 \%, 3 \%$, and $4 \%)$ methanol as the negative control, and chloramphenicol at a dose of $3.4 \%$ as the positive control. The immersed paper discs were then placed on the plates. These plates were then incubated overnight at $27^{\circ} \mathrm{C}$. Each dose had five replicates. The dose of banana midrib extract that resulted in the largest inhibition zone diameter was used for subsequent tests in this study.

\section{Experimental Diet}

The experimental diet was prepared by mixing commercial fish feed (Prima Feed PF 1000; PT Matahari Sakti, Indonesia) and banana midrib extract with the dose found effective in the antimicrobial activity test. The mixing step was performed in a feed container by spraying banana midrib extract onto the feed slowly (Harikrishnan et al., 2010). Next, 2\% egg white was added to this mixture as a binder. The control diet was prepared by mixing commercial fish feed with $2 \%$ egg white without adding banana midrib extract. Experimental and control diets were dried at room temperature for a day before use.

\section{Fish and Containers}

The experimental fish used in this study was giant gourami with an average weight of $15.7 \pm 0.31 \mathrm{~g}$, collected from local farmers in Bogor, West Java, Indonesia. Fish were acclimatized for a week before experimental treatments. During the acclimatization period, fish were fed commercial fish feed three times a day at a feeding rate of $3 \%$ of the biomass. Fish were reared in 15 glass aquariums sized $60 \times 30 \times 30 \mathrm{~cm}^{3}$ with a water level of $20 \mathrm{~cm}$ and a stocking density of 10 fish per aquarium. Water temperature was maintained in a stable range using a thermostat in each aquarium. Aeration was provided to each experimental aquarium through an aeration unit connected to an air blower. The outer parts of aquariums were covered with black lowdensity polyethene plastic to prevent physiological stress in experimental fish.

\section{Experimental Design}

The experiment was conducted through a completely randomized design comprising five treatments. This study evaluated the effects of dietary banana midrib extract on giant gourami under different exposure approaches against $A$. hydrophila using a modified protocol from the study by Pattah et al. (2020). The different exposure approaches were preventive, curative, and controlling and were compared with control treatments, including negative and positive controls without dietary banana midrib extract. Detailed experimental illustration is presented in Figure 1. Each treatment group included 30 fish. Each group of treatments was applied in triplicates in this experiment. Overall, 150 fish (5 groups $\times 30$ fish) were used and randomly distributed to 15 glass aquariums.

Feeding frequency for the fish was three times a day, in the morning, noon, and afternoon, with a $3 \%$ feeding rate. Fish were reared for 14 days. On day 14, all treatments except negative control were challenged with $A$. hydrophila at a suspension volume of $0.1 \mathrm{~mL}$ per

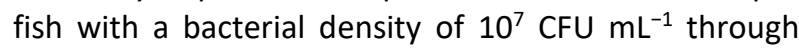
intraperitoneal injection. After the challenge test, banana midrib extract-enriched feed was administered to the experimental fish in controlling and curative treatments. In contrast, the fish in other treatments were given commercial feed coated with $2 \%$ egg white without banana midrib extract. Enriched feed was given

Table 1. Results of the identification of Aeromonas hydrophila and Streptococcus agalactiae NK1

\begin{tabular}{lcc}
\hline Characteristics & Aeromonas hydrophila & Streptococcus agalactiae NK1 \\
\hline Gram & Negative & Positive \\
Shape & Rod & Round \\
Oxidative/fermentative & Fermentative & Fermentative \\
Catalase & + & - \\
Oxidase & + & - \\
Motility & Motile & Non-motile \\
\hline
\end{tabular}




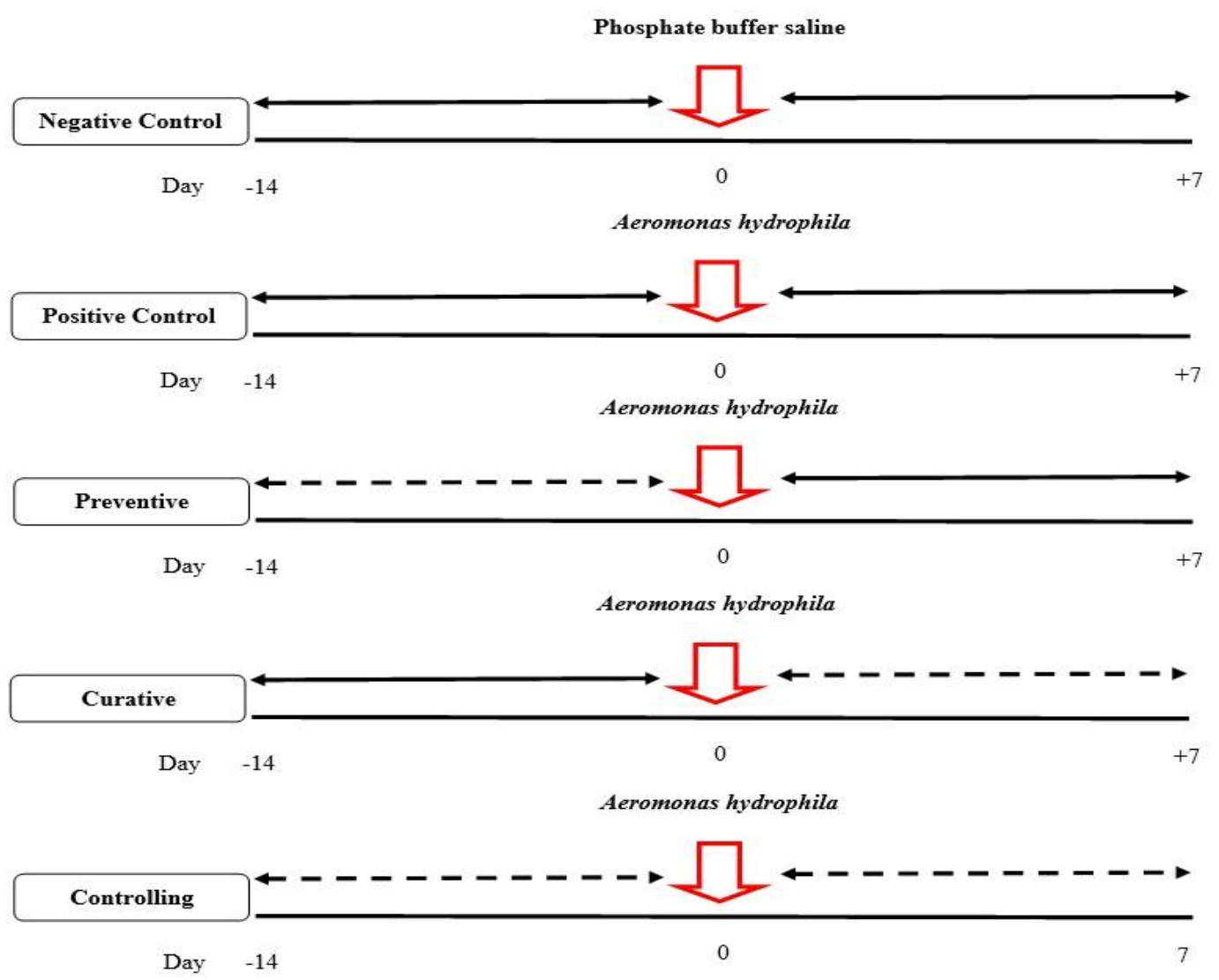

Figure 1. Experimental design illustration

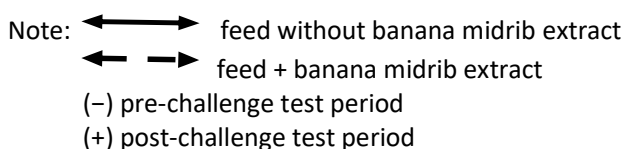

to the fish in curative treatment after clinical symptoms of $A$. hydrophila were shown, which was triggered on 1 day after the challenge test (day+1). After the challenge test, the fish were reared for 7 days.

Uneaten feed and feces were removed from the rearing medium after $4 \mathrm{~h}$ of feeding to maintain optimum water quality. Water replacement $(30 \%$ of total water volume) was performed every 2 days. Water quality parameters, including $\mathrm{pH}$, temperature, dissolved oxygen, and total ammonia nitrogen, were checked every week following APHA (1995). Water quality during rearing activity was optimum for giant gourami: $\mathrm{pH}(6.26-7.80)$, temperature $\left(28^{\circ} \mathrm{C}-32^{\circ} \mathrm{C}\right)$, dissolved oxygen $(7.0-8.2 \mathrm{ppm})$, and total ammonia nitrogen (0.009-0.05 ppm).

\section{Blood Sampling}

Blood samples were collected on day-14 and day-1 of the challenge test and day $+2, \mathrm{day}+5$, and day +7 of the challenge test. The samples were randomly collected from 3 fish/group. Before blood sampling, the fish were anesthetized using MS-222 at a dose of $50 \mathrm{mg} / \mathrm{L}$ of water. The blood was collected from the caudal vein using a $1 \mathrm{~mL} 27$-gauge syringe needle rinsed with an anticoagulant ( $10 \%$ trisodium citrate). Individual fish were sampled once to prevent the effect of on the assays due to multiple bleeding and handling stress of the fish.

\section{Observation of Blood Profile and Immune Responses}

Hematocrit level was measured with the microcentrifuge method described by Anderson and Siwicki (1995), using standard heparinized microhematocrit capillary tubes $(75 \mathrm{~mm}$ at $7000 \mathrm{~g}$ for 10 minutes). Total leukocyte count was manually counted by hemocytometry method according to the method described by Blaxhall and Daisley (1973), using Neubauer hemocytometer after diluting blood samples with Turk solution. Respiratory burst activity was measured using nitro blue tetrazolium reagent following the method explained by Secombes (1990). Lysozyme activity was measured using a microtiter plate ELISA reader at a wavelength of $520 \mathrm{~nm}$ according to the procedure outlined by Soltani and Pourgholam (2007).

\section{Observation of Infection Rate and Disease Resistance}

The infection rate was expressed by clinical symptoms, feed consumption, prevalence, and total $A$. hydrophila in the experimental fish, whereas disease 
resistance was expressed by survival. Clinical symptoms were observed during 7 days of the post-challenge test period. Each fish had a clinical symptom score which was accumulated at the end of the challenge test. The scoring was based on the method described by Angka (2005) with the following scores: inflammations $=1$, hemorrhages $=2$, ulcers $=3$, and mortality $=4$. Clinical symptoms were supported by the feed consumption rate. The infected fish would have less feed consumption than the healthy fish. Feed consumption was recorded daily during this study. Prevalence was calculated at the end of the challenge test. The enumeration of total $A$. hydrophila in the experimental fish was conducted on day 5 of the challenge test. The samples were randomly selected from each experimental group. The organs collected for the enumeration of total $A$. hydrophila were kidneys. Total $A$. hydrophila was enumerated using the total plate count technique. Survival of the experimental fish was recorded daily during the experiment.

\section{Data Analysis}

The obtained data were processed using Microsoft Excel 2019. The quantitative data were then analyzed through statistical tests, including one-way ANOVA and Tukey's test, using IBM ${ }^{\oplus}$ SPSS ${ }^{\oplus}$ Statistics software version 22 (IBM Corp., Armonk, New York, USA) after being subjected to Shapiro-Wilk's test and Levene's test to verify the normality and homogeneity of the variances. All statistical tests were significant at $P<0.05$. In addition, quantitative data were obtained from several parameters with a minimum $\mathrm{n}=3$, including blood profile (hematocrit level and total leukocyte count), total A. hydrophila population in the experimental fish, survival, respiratory burst, and lysozyme activities. Other data obtained from the following parameters with $\mathrm{n}<3$, including inhibition zone diameter, phytochemical contents of the banana midrib, total feed consumption, prevalence, leukocyte differential count, and clinical symptoms scores, were analyzed through descriptive statistics.

\section{Results}

\section{Phytochemical Contents of Banana Midrib}

The preliminary screening of bioactive compounds in banana midrib extracts showed that banana midrib contained active compounds such as alkaloids, flavonoids, triterpenoids, steroids, tannins, phenolics, and glycosides. The quantification of each compound found in the preliminary screening indicated that banana midrib contained high flavonoid content (28.10\%) as presented in Table 2.

\section{Antimicrobial Activity of Banana Midrib Extract}

Banana midrib extract showed antimicrobial activity against $A$. hydrophila and $S$. agalactiae NK1 indicated by inhibition zone diameter on the disc diffusion assay. Optimum antimicrobial activity was found in the extract dose of $3 \%$, resulting in an inhibition zone diameter of $1.15 \pm 0.10 \mathrm{~cm}$ against $A$. hydrophila and an inhibition zone diameter of $0.75 \pm 0.10 \mathrm{~cm}$ against $S$ agalactiae NK1 (Table 3 ). This dose was then applied to prepare an experimental diet for the subsequent experiment.

Table 2. Phytochemical contents of banana (Musa paradisiaca) midrib extract

\begin{tabular}{lc}
\hline Phytochemical compounds & Percentage (\%) \\
\hline Flavonoid & 28.10 \\
Alkaloid & 18.27 \\
Triterpenoid & 11.39 \\
Phenolic & 8.32 \\
Saponin & 8.12 \\
Tannin & 6.10 \\
Steroid & 0.11 \\
Glycoside & 0.10 \\
\hline
\end{tabular}

Note: listed numbers in the table are averages.

Table 3. Antimicrobial activity of banana (Musa paradisiaca) midrib extract against Aeromonas hydrophila and Streptococcus agalactiae NK1

\begin{tabular}{lcc}
\hline Treatments & $\begin{array}{c}\text { Inhibition zone diameter against Aeromonas } \\
\text { hydrophila }(\mathrm{cm})\end{array}$ & $\begin{array}{c}\text { Inhibition zone diameter against Streptococcus } \\
\text { agalactiae NK1 (cm) }\end{array}$ \\
\hline Chloramphenicol 3.4\% & $0.55 \pm 0.01$ & $0.00 \pm 0.00$ \\
Methanol & $0.00 \pm 0.00$ & $0.00 \pm 0.00$ \\
Banana midrib 1\% & $0.80 \pm 0.08$ & $0.55 \pm 0.03$ \\
Banana midrib 2\% & $0.93 \pm 0.96$ & $0.62 \pm 0.01$ \\
Banana midrib 3\% & $1.15 \pm 0.10$ & $0.75 \pm 0.10$ \\
Banana midrib 4\% & $1.15 \pm 0.18$ & $0.69 \pm 0.01$ \\
\hline
\end{tabular}

Note: listed numbers in the table are averages and standard deviations. 


\section{Survival, Scores of Clinical Symptoms, Prevalence, and} Total Aeromonas hydrophila in the Experimental Fish

Clinical symptoms, prevalence, and total $A$. hydrophila in the experimental fish indicated the infection rate supported by fish survival. The infection of A. hydrophila caused several clinical symptoms such as inflammation, hemorrhage, ulcer, and mortality. The most found clinical symptom in this experiment was ulcer followed by mortality. The highest clinical symptom score was found in the positive control, whereas the lowest clinical symptom score was found in the negative control, followed by preventive, curative, and controlling treatments (Table 4). The positive control showed a larger ulcer than other treatment groups (Figure 2). The highest prevalence (100\%) was obtained in the positive control, followed by the lowest survival $(60 \% \pm 0 \%)$. The negative control showed no prevalence with survival of $100 \% \pm 0 \%$. The optimum result was demonstrated by curative treatment with survival of $100 \% \pm 0 \%$ that was not significantly different from that of the controlling treatment $(97.5 \% \pm 5 \%)$. These results were supported by lower total $A$. hydrophila values in preventive, curative, and controlling treatments $\left(1.6 \times 10^{7}, 1.2 \times 10^{7}\right.$, and $8.0 \times 10^{6}$ CFU $\mathrm{g}^{-1}$ ) than that in positive control with a total $A$. hydrophila of $3.0 \times 10^{8} \mathrm{CFU} \mathrm{g}^{-1}$ (Table 5).

\section{Feed Consumption Before and After the Challenge Test}

Feed consumption before the challenge test was 6 $\mathrm{g}$ in all treatments. After the challenge test, it drastically decreased and increased again 2 days after the challenge test. The lowest feed consumption was found in positive control treatment (Figure 3 ).

Table 4. Clinical symptoms scores obtained in giant gourami (Osphronemus gouramy) after the challenge test with Aeromonas hydrophila

\begin{tabular}{|c|c|c|c|c|c|}
\hline \multirow[t]{2}{*}{ Treatments } & \multicolumn{4}{|c|}{ Clinical symptoms scores } & \multirow[t]{2}{*}{ Total } \\
\hline & Inflammation & Hemorrhage & Ulcer & Mortality & \\
\hline Positive control & 0 & 0 & 54 & 48 & 102 \\
\hline Negative control & 0 & 0 & 0 & 0 & 0 \\
\hline Preventive & 0 & 0 & 3 & 8 & 11 \\
\hline Curative & 1 & 2 & 15 & 0 & 18 \\
\hline Controlling & 0 & 6 & 9 & 4 & 19 \\
\hline Total & 1 & 8 & 81 & 60 & 150 \\
\hline
\end{tabular}
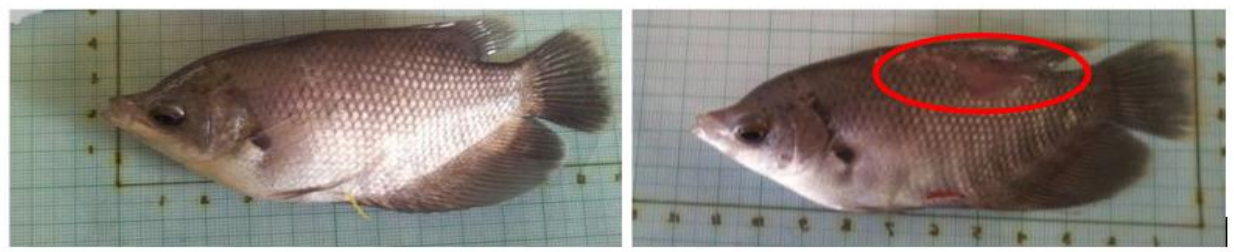

A. Negative control: $0.0 \mathrm{~cm}$ (ulcer length)

B. Positive control: $4.5 \mathrm{~cm}$ (ulcer length)
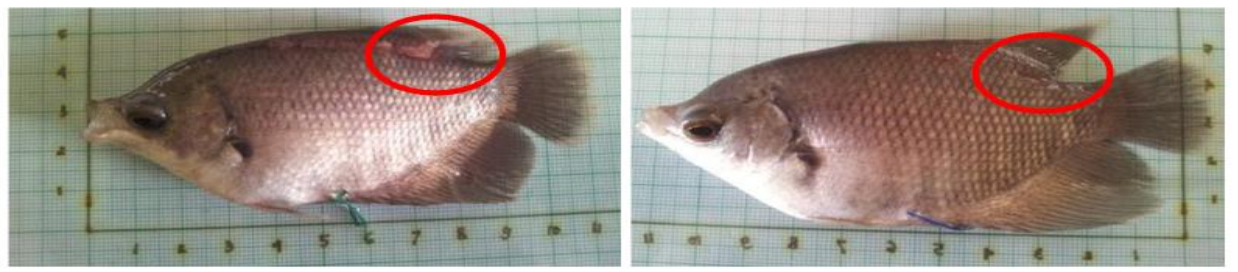

C. Preventive: $3.8 \mathrm{~cm}$ (ulcer length)
D. Curative: $3.5 \mathrm{~cm}$ (ulcer length)

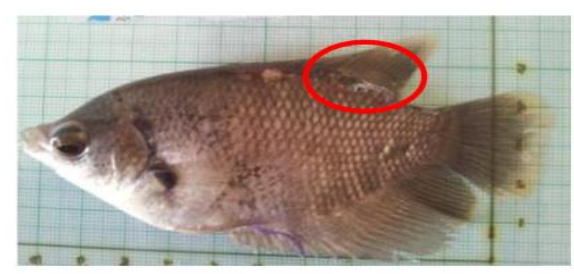

E. Controlling: $3.7 \mathrm{~cm}$ (ulcer length)

Figure 2. Ulcer appearances on the healthy fish (negative control group) and the infected fish (positive control, preventive, curative, and controlling groups) 
Table 5. Survival, prevalence, and total Aeromonas hydrophila of giant gourami (Osphronemus gouramy) during treatments using banana (Musa paradisiaca) midrib extract

\begin{tabular}{|c|c|c|c|c|c|}
\hline \multirow[t]{2}{*}{ Parameters } & \multicolumn{5}{|c|}{ Treatments } \\
\hline & Negative control & Positive control & Preventive & Curative & Controlling \\
\hline Survival (\%) & $100 \pm 0^{c}$ & $60 \pm 0^{a}$ & $92.5 \pm 5^{b}$ & $100 \pm 0^{c}$ & $97.5 \pm 5^{c}$ \\
\hline Prevalence (\%) & 0 & 100 & 6.7 & 20 & 6.7 \\
\hline Total Aeromonas hydrophila $\left(\times 10^{7} \mathrm{CFU} \mathrm{g}^{-1}\right)$ & $0.4^{a}$ & $30^{b}$ & $1.6^{\mathrm{a}}$ & $1.2^{\mathrm{a}}$ & $0.8^{\mathrm{a}}$ \\
\hline
\end{tabular}

Note: different superscript letters in each row indicate significant differences $(P<0.05)$.

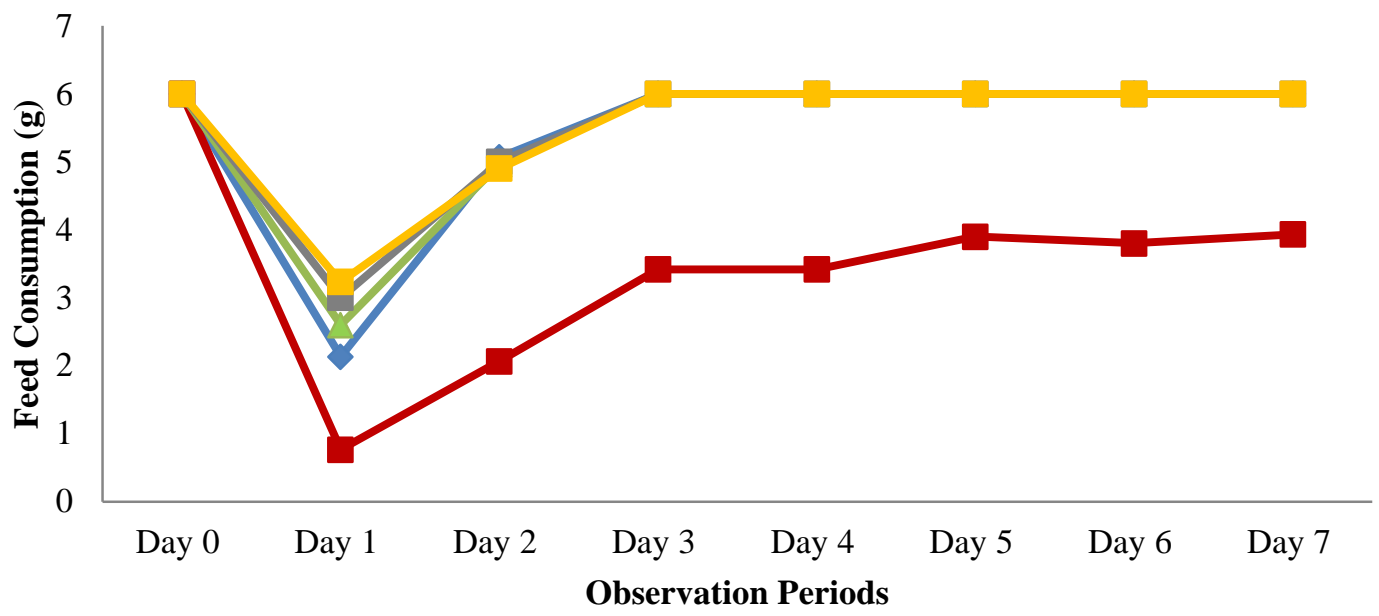

$\rightarrow$ Negative Control $\rightarrow-$ Positive Control $\triangle$ Curative $\rightarrow-$ Preventive - Controlling

Figure 3. Feed consumption of giant gourami (Osphronemus gouramy) before and after the challenge test with Aeromonas hydrophila. Day 0: before the challenge test and Day 1-7: after the challenge test.

\section{Blood Profile and Immune Responses of Experimental Fish}

The blood profile of experimental fish was expressed by hematocrit level and total leukocyte count. Immune responses of experimental fish were represented by lysozyme activity, respiratory burst activity, and differential leukocyte count. Hematocrit level and total leukocyte count of giant gourami in this study are presented in Table 6 . Before the challenge test, hematocrit levels of experimental fish were relatively at the same level among all treatments. After the challenge test, hematocrit levels decreased and increased on day 5 after the challenge test. On day 5 after the challenge test, the highest hematocrit level was obtained with curative treatment $(26.00 \% \pm 0.35 \%)$ that was significantly different compared with those obtained with the positive control, negative control, and preventive and controlling treatments $(17.80 \% \pm 0.14 \%$, $21.28 \% \pm 0.90 \%, 24.00 \% \pm 0.14 \%$, and $22.20 \% \pm 0.14 \%$ ) Total leukocyte counts in preventive, curative, and controlling treatments showed a similar trend, with hematocrit levels increasing on day 5 after the challenge test. On day 5 after the challenge test, there was no difference in total leukocyte counts among preventive, curative, and controlling treatments $(4.75 \pm 0.21,4.30 \pm$
0.28 , and $4.68 \pm 0.17 \times 10^{5}$ cells $\mathrm{mm}^{-3}$ ) and were significantly different from that in the positive control $\left(3.52 \pm 0.11 \times 10^{5}\right.$ cells $\left.\mathrm{mm}^{-3}\right)$.

Lysozyme and respiratory burst activities of giant gourami in this experiment are summarized in Table 7. Before the challenge test, lysozyme and respiratory burst activities were at the same level among all treatments. However, lysozyme activity in each treatment declined after the challenge test and increased on day 5 after the challenge test on preventive, curative, and controlling treatments. On day 5 after the challenge test, lysozyme activities in preventive, curative, and controlling treatments (449.67 $\pm 1.527,441.33 \pm 3.214$, and $499.67 \pm 1.527 \mathrm{UI} \mathrm{mL}^{-1}$ minutes $^{-1}$ ) were significantly different from that in the positive control $\left(200.00 \pm 5.000 \mathrm{UI} \mathrm{mL}^{-1}\right.$ minutes $\left.^{-1}\right)$. The same pattern also occurred at the end of the experiment. On day 5 after the challenge test, respiratory burst activities in preventive, curative, and controlling treatments $(0.64 \pm 0.002,0.67 \pm 0.002$, and $0.63 \pm 0.048$ OD $630 \mathrm{~nm})$ were significantly different from that in the positive control $(0.35 \pm 0.004$ OD 630 $\mathrm{nm})$. That indicated the effect of the treatments applied on the immune responses of experimental fish after infection with $A$. hydrophila. 
Leukocyte differential count was performed to observe the percentages of specific leukocyte cells such as lymphocytes, neutrophils, and monocytes (Table 8). Lymphocytes dominated the leukocyte profile of giant gourami, followed by neutrophils and monocytes. The infection of $A$. hydrophila caused a decrease in lymphocyte count in all treatments and an increase in neutrophil count after infection with $A$. hydrophila. Moreover, monocytes were found after giant gourami infected by $A$. hydrophila. Monocytes were not found in preventive, curative, and controlling treatments at the end of the experiment.

\section{Discussion}

Banana midrib extract had antimicrobial activity against Gram-positive and Gram-negative bacteria. The inhibition zone obtained in disc diffusion assay indicates that banana midrib has phytochemical substances working against bacteria (Citarasu, 2010). Phytochemical substances contained in banana midrib extract were dominated by flavonoid. Antimicrobial activity of banana midrib extract was found to be higher against Gram-negative bacterial species than against Gram-positive bacterial species. It could be assumed that the flavonoid present in banana midrib extract was from flavones. Flavonoids were classified into five different groups, including flavones, flavonols, flavonones, flavononol, and isoflavones. Flavones have the highest dilution rate against lipids (Kumar \& Pandey, 2013). The cell wall of $A$. hydrophila mostly comprises lipids or lipopolysaccharides (LPS). Therefore, flavone has a better chance of destroying Gram-negative bacterial cell wall than that of Gram-positive bacterial cell wall, mostly comprising peptidoglycan (Fitrianingrum, 2015).

Banana midrib extract was effective as a curative agent against MAS demonstrated by a high survival of giant gourami infected by $A$. hydrophila. It is correlated with flavonoids in banana midrib that work as an antibacterial agent. Furthermore, banana midrib extract application induced the innate immunity of fish, leading to higher survival of giant gourami than that without any treatments.

The activity of flavonoids as destruction substances against Gram-negative bacteria was proven by lower total $A$. hydrophila counts in preventive, curative, and controlling treatments than that in the positive control. Similar results were reported by Immanuel et al. (2004) that the enrichment of Artemia with flavonoid from seaweed given to shrimp reduced the number of Vibrio parahaemolyticus from $3.86 \times 10^{5} \mathrm{CFU} \mathrm{g}^{-1}$ to $1.36 \times 10^{5}$ CFU $\mathrm{g}^{-1}$. Thus, flavonoids can inhibit pathogenic bacterial activity by improving the generation of reactive oxygen species (ROS) by macrophages. In addition, the increase in leukocyte proliferation, bactericidal serum activity, and superoxidase production (Citarasu, 2010) aids phagocytic activity and the elimination of antigens inside the fish body, thereby causing a reduction in the number of pathogenic bacteria.

Clinical symptoms after $A$. hydrophila infection include the occurrence of hyperemia followed by inflammation, hemorrhage, and ulcer (Wahjuningrum et al., 2010). Ulcer became the most noted abnormality in giant gourami. It was caused by the toxin produced by A. hydrophila. This pathogen produces hemolysin that lyses erythrocytes and causes hemoglobin loss (Istikhanah et al., 2014). Hemolysin can disrupt epidermis and fin tissues, leading to ulcer formation on the fish body (Mangunwardoyo et al., 2010). The application of banana midrib extract as preventive, curative, and controlling agents for $A$. hydrophila could reduce the abnormalities caused by $A$. hydrophila infection. The phytochemical compounds in banana midrib extract, such as flavonoid, alkaloid, saponin, and tannin, had a role as antibacterial substances which could inhibit the function of the bacterial cell membrane and led to the destruction of the bacterial cell wall (Wahjunigrum et al., 2010). Moreover, flavonoids function as anti-inflammatory agents (Haryani et al., 2012), reducing inflammation during $A$. hydrophila infection. The healing process of injury caused by $A$. hydrophila infection comprised three phases: inflammatory, neo capillary (forming of the new capillary), and re-epithelial (formation of the epithelium). During the injury healing phases, leukocytes such as neutrophils, macrophages, and lymphocytes are in action (Febram et al., 2010). The flavonoid in banana midrib extract enhances leukocyte proliferation, leading to a faster injury healing process after $A$. hydrophila infection according to Christybapita et al. (2007), who stated that flavonoids could increase cellular adaptive immune response, thereby increasing leukocyte proliferation. The high number of leukocytes is correlated to neutrophils, macrophages, and lymphocytes.

The decrease in feed consumption after an experimental infection with $A$. hydrophila indicated the stress in the fish. According to Harper and Wolf (2009), a stressed fish after an experimental infection will suffer a decrease in appetite and thus reduced total feed consumption. Moreover, A. hydrophila can cause intestinal damage followed by anorexia (Yardimci \& Aydin, 2011). The intestinal damage is caused by a large amount of cytotoxin that causes cell necrosis in the intestine (Donta \& Haddow, 1978). Fish appetite will normalize after the stress response disappears. A faster recovery process in giant gourami treated with banana midrib extract led to higher fish consumption during an experimental infection with $A$. hydrophila.

Hematological parameters are used as indicators of the health status of the fish, particularly the presence of disease or stressful conditions (Osman et al., 2010; Karimi et al., 2013; Suely et al., 2016). Thus, hematological indices such as total leukocyte count, total erythrocyte count, hemoglobin level, and 
Table 6. Hematocrit level and total leukocyte count of giant gourami (Osphronemus gouramy) treated with banana (Musa paradisiaca) midrib extract before and after the challenge test with Aeromonas hydrophila

\begin{tabular}{|c|c|c|c|c|c|c|}
\hline \multirow[t]{2}{*}{ Parameters } & \multirow[t]{2}{*}{ Observation periods } & \multicolumn{5}{|c|}{ Treatments } \\
\hline & & Negative control & Positive control & Preventive & Curative & Controlling \\
\hline Hematocrit & Day-14 & $20.00 \pm 0.35^{a}$ & $20.00 \pm 0,35^{a}$ & $20.00 \pm 0.35^{a}$ & $20.00 \pm 0.35^{a}$ & $20.00 \pm 0.35^{a}$ \\
\hline \multirow[t]{4}{*}{ level (\%) } & Day-1 & $21.23 \pm 0.52^{\mathrm{a}}$ & $21.50 \pm 0.35^{a}$ & $25.06 \pm 0.70^{b}$ & $21.23 \pm 0.14^{a}$ & $25.17 \pm 0.71^{b}$ \\
\hline & Day+2 & $20.00 \pm 0.35^{a}$ & $19.00 \pm 0.70^{a}$ & $22.50 \pm 0.35^{b}$ & $22.20 \pm 0.21^{b}$ & $22.20 \pm 0.21^{b}$ \\
\hline & Day+5 & $21.28 \pm 0.90^{b}$ & $17.80 \pm 0.14^{\mathrm{a}}$ & $24.00 \pm 0.14^{c}$ & $26.00 \pm 0.35^{d}$ & $22.20 \pm 0.14^{b}$ \\
\hline & Day+7 & $32.00 \pm 0.35^{b}$ & $18.00 \pm 0.08^{a}$ & $32.30 \pm 0,07^{b}$ & $33.04 \pm 0.04^{b}$ & $36.50 \pm 0.35^{c}$ \\
\hline Total & Day-14 & $3.00 \pm 0.07^{a}$ & $3.00 \pm 0.07^{a}$ & $3.00 \pm 0.07^{a}$ & $3.00 \pm 0.07^{a}$ & $3.00 \pm 0.07^{a}$ \\
\hline leukocyte & Day-1 & $3.10 \pm 0.01^{\mathrm{a}}$ & $3.10 \pm 0.01^{\mathrm{a}}$ & $3.80 \pm 0.07^{b}$ & $3.10 \pm 0.01^{\mathrm{a}}$ & $3.80 \pm 0.07^{b}$ \\
\hline count & Day+2 & $3.15 \pm 0.07^{a}$ & $3.35 \pm 0.07^{a}$ & $4.35 \pm 0.21^{c}$ & $3.75 \pm 0.07^{b}$ & $4.23 \pm 0.10^{c}$ \\
\hline (x $10^{5}$ cells & Day+5 & $3.30 \pm 0.14^{a}$ & $3.52 \pm 0.11^{\mathrm{a}}$ & $4.75 \pm 0.21^{b}$ & $4.30 \pm 0.28^{b}$ & $4.68 \pm 0.17^{b}$ \\
\hline $\left.\mathrm{mm}^{-3}\right)$ & Day+7 & $3.50 \pm 0.14^{\mathrm{ab}}$ & $3.58 \pm 0.03^{b}$ & $3.06 \pm 0.31^{\mathrm{a}}$ & $3.40 \pm 0.07^{a b}$ & $3.17 \pm 0.28^{a}$ \\
\hline
\end{tabular}

Note: listed numbers are averages and standard deviations. Different superscript letters in each row indicate significant differences $(P<0.05)$. $(-)$ : pre-challenge test period; (+): post-challenge test period.

Table 7. Lysozyme and respiratory burst activities of giant gourami (Osphronemus gouramy) treated with banana (Musa paradisiaca) midrib extract before and after the challenge test with Aeromonas hydrophila

\begin{tabular}{lcccccc}
\hline Parameters & Observation & \multicolumn{5}{c}{ Treatments } \\
\cline { 3 - 7 } & periods & Negative control & Positive control & Preventive & Curative & Controlling \\
\hline Lysozyme & Day-14 & $259.33 \pm 4.041^{\mathrm{a}}$ & $259.33 \pm 4.041^{\mathrm{a}}$ & $259.33 \pm 4.041^{\mathrm{a}}$ & $259.33 \pm 4.041^{\mathrm{a}}$ & $259.33 \pm 4.041^{\mathrm{a}}$ \\
activity (UI & Day-1 & $261.33 \pm 3.214^{\mathrm{a}}$ & $261.33 \pm 3.214^{\mathrm{a}}$ & $314.33 \pm 3.214^{\mathrm{b}}$ & $261.33 \pm 3.214^{\mathrm{a}}$ & $314.33 \pm 3.214^{\mathrm{b}}$ \\
$\mathrm{mL}^{-1}$ & Day+2 & $203.67 \pm 3.214^{\mathrm{a}}$ & $207.00 \pm 3.000^{\mathrm{a}}$ & $214.00 \pm 3.605^{\mathrm{a}}$ & $325.00 \pm 5.000^{\mathrm{b}}$ & $355.00 \pm 5.000^{\mathrm{c}}$ \\
minutes $^{-1}$ ) & Day+5 & $220.00 \pm 5.000^{\mathrm{b}}$ & $200.00 \pm 5.000^{\mathrm{a}}$ & $449.67 \pm 1.527^{\mathrm{d}}$ & $441.33 \pm 3.214^{\mathrm{c}}$ & $499.67 \pm 1.527^{\mathrm{e}}$ \\
& Day+7 & $222.00 \pm 2.000^{\mathrm{b}}$ & $180.00 \pm 9.000^{\mathrm{a}}$ & $285.00 \pm 5.000^{\mathrm{d}}$ & $250.00 \pm 5.000^{\mathrm{c}}$ & $305.00 \pm 5.000^{\mathrm{e}}$ \\
\hline Respiratory & Day-14 & $0.27 \pm 0.014^{\mathrm{a}}$ & $0.27 \pm 0.014^{\mathrm{a}}$ & $0.27 \pm 0.014^{\mathrm{a}}$ & $0.27 \pm 0.014^{\mathrm{a}}$ & $0.27 \pm 0.014^{\mathrm{a}}$ \\
burst & Day-1 & $0.25 \pm 0.007^{\mathrm{a}}$ & $0.25 \pm 0.007^{\mathrm{a}}$ & $0.28 \pm 0.007^{\mathrm{a}}$ & $0.25 \pm 0.007^{\mathrm{a}}$ & $0.28 \pm 0.007^{\mathrm{a}}$ \\
activity (OD & Day+2 & $0.21 \pm 0.004^{\mathrm{a}}$ & $0.34 \pm 0.001^{\mathrm{b}}$ & $0.46 \pm 0.044^{\mathrm{b}}$ & $0.36 \pm 0.014^{\mathrm{b}}$ & $0.45 \pm 0.007^{\mathrm{b}}$ \\
630 nm) & Day+5 & $0.25 \pm 0.020^{\mathrm{a}}$ & $0.35 \pm 0.004^{\mathrm{b}}$ & $0.64 \pm 0.002^{\mathrm{c}}$ & $0.67 \pm 0.002^{\mathrm{c}}$ & $0.63 \pm 0.048^{\mathrm{c}}$ \\
& Day+7 & $0.26 \pm 0.003^{\mathrm{ab}}$ & $0.34 \pm 0.001^{\mathrm{b}}$ & $0.23 \pm 0.001^{\mathrm{a}}$ & $0.25 \pm 0.001^{\mathrm{ab}}$ & $0.25 \pm 0.002^{\mathrm{ab}}$ \\
\hline
\end{tabular}

Note: listed numbers are averages and standard deviations. Different superscript letters in each row indicate significant differences $(P<0.05)$. $(-)$ : pre-challenge test period; (+): post-challenge test period.

Table 8. Leukocyte differential count of giant gourami (Osphronemus gouramy) treated with banana (Musa paradisiaca) midrib extract before and after the challenge test with Aeromonas hydrophila

\begin{tabular}{|c|c|c|c|c|c|c|}
\hline \multirow{2}{*}{$\begin{array}{l}\text { Leukocyte } \\
\text { differential count }\end{array}$} & \multirow[t]{2}{*}{ Observation periods } & \multicolumn{5}{|c|}{ Treatments } \\
\hline & & Negative control & Positive control & Preventive & Curative & Controlling \\
\hline \multirow[t]{5}{*}{ Neutrophils (\%) } & Day-14 & $12 \pm 0.707$ & $12 \pm 1.414$ & $12 \pm 0.707$ & $12 \pm 0.707$ & $12 \pm 0.707$ \\
\hline & Day-1 & $12 \pm 2.121$ & $12 \pm 2.121$ & $23 \pm 2.121$ & $12 \pm 2.121$ & $23 \pm 2.121$ \\
\hline & Day+2 & $15 \pm 0.701$ & $25 \pm 0.707$ & $25 \pm 0.707$ & $30 \pm 0.414$ & $27 \pm 0.707$ \\
\hline & Day+5 & $30 \pm 0.121$ & $49 \pm 0.707$ & $20 \pm 1.414$ & $18 \pm 0.707$ & $17 \pm 0.707$ \\
\hline & Day+7 & $27 \pm 2.121$ & $37 \pm 0.707$ & $14 \pm 0.707$ & $19 \pm 0.707$ & $17 \pm 0.707$ \\
\hline \multirow[t]{5}{*}{ Monocytes (\%) } & Day-14 & $0 \pm 0.000$ & $0 \pm 0.000$ & $0 \pm 0.000$ & $0 \pm 0.000$ & $0 \pm 0.000$ \\
\hline & Day-1 & $0 \pm 0.000$ & $0 \pm 0.000$ & $0 \pm 0.000$ & $0 \pm 0.000$ & $0 \pm 0.000$ \\
\hline & Day+2 & $0 \pm 0.000$ & $15 \pm 1.414$ & $15 \pm 1.414$ & $20 \pm 1.414$ & $12 \pm 0.707$ \\
\hline & Day+5 & $10 \pm 0.707$ & $20 \pm 1.414$ & $5 \pm 2.121$ & $10 \pm 0.707$ & $9 \pm 1.414$ \\
\hline & Day+7 & $8 \pm 0.000$ & $15 \pm 1.121$ & $0 \pm 0.000$ & $0 \pm 0.000$ & $0 \pm 0.000$ \\
\hline \multirow[t]{5}{*}{ Lymphocytes (\%) } & Day-14 & $88 \pm 0.707$ & $88 \pm 0.707$ & $88 \pm 0.707$ & $88 \pm 0.707$ & $88 \pm 0.707$ \\
\hline & Day-1 & $88 \pm 2.121$ & $88 \pm 2.121$ & $77 \pm 2.121$ & $88 \pm 0.212$ & $77 \pm 2.121$ \\
\hline & Day+2 & $85 \pm 0.707$ & $60 \pm 0.000$ & $60 \pm 0.707$ & $50 \pm 0.282$ & $61 \pm 0.000$ \\
\hline & Day+5 & $60 \pm 2.828$ & $31 \pm 0.707$ & $75 \pm 0.707$ & $72 \pm 0.000$ & $74 \pm 2.121$ \\
\hline & Day+7 & $65 \pm 2.121$ & $48 \pm 2.828$ & $86 \pm 0.707$ & $81 \pm 2.121$ & $83 \pm 0.707$ \\
\hline
\end{tabular}

Note: listed numbers are averages and standard deviations. (-): pre-challenge test period; (+): post-challenge test period. 
leukocyte differential count play important roles in assessing the physiological condition of the fish.

The infection of $A$. hydrophila caused a decrease in hematocrit levels in all treatments owing to the lysis of erythrocytes (Wahjuningrum et al., 2020). The reduction in hematocrit level may be caused by blood loss, hemodilution, and osmoregulatory dysfunction. It is related to a disruption in anterior kidney function, because it is the primary organ for hemopoiesis (Koeypudsa \& Jongjareanjai, 2010). Giant gourami treated with banana midrib extract had higher hematocrit levels than the fish without any treatments. Flavonoids contained in banana midrib extract played a role as an antioxidant that neutralized free radicals and had a role in the recovery of blood cell structure through erythropoiesis (Fajriyani et al., 2017). In addition, flavonoids positively reduce the lysis of erythrocytes caused by a bacterial infection via protection of erythrocytes' biological membranes (Kitagawa et al., 1992; Asgary et al., 2005).

Leukocytes function as nonspecific immune systems that destroy pathogens through phagocytosis (Sukenda et al., 2008). The infection of $A$. hydrophila caused an increase in total leukocyte count. It was correlated to higher phagocytic activity as the result of the bacterial infection. It indicates that the immune system works to combat bacterial infection. Low total leukocyte count in preventive, curative, and controlling treatments at the end of the experiment was correlated with the immunomodulatory properties of banana midrib extract. Wahjuningrum et al. (2010) stated that flavonoids can enhance the immune responses of the fish.

Lysozyme works as a phagocyte, complementary activation, and opsonin (Callewaert \& Michiels, 2010). During the post-challenge test period, lysozyme activity increased in the groups treated with banana midrib extract. Giant gourami fed with banana midrib diet had higher lysozyme activities than untreated fish. The addition of flavonoids in the feed can increase leukocyte activation, leading to improved lysozyme secretion.

Respiratory burst activity is a method used to examine the ability of phagocytic cells to reduce microbes by producing radical oxygen (lelpo et al., 2000). Flavonoid works as an antioxidant by inducing radical oxygen. The hydroxyl group in flavonoids would exert its effect by breaking radical oxygen and chelating ions. Flavonoid as a hydrogen and electron donor works as a stabilizer of radicals. Therefore, the increasing formation of ROS and decreasing secretion of microsomal monooxygenase enzymes trigger free radicals (Kumar \& Pandey, 2013). Higher respiratory burst activity indicates higher induction of phagocytes to reduce the microbial population, whereas lower respiratory burst activity indicates that microbes were being eliminated from the host (Logambal et al., 2000).

The administration of banana midrib extract in the fish diet resulted in positive impact on lymphocyte count. The increases in lymphocytes, monocytes, neutrophils, and eosinophils, which are the basic elements of the defense system, demonstrate the effect of herbal plants on body defenses (Şahan et al., 2016). Lymphocytes function to produce antibodies, acknowledge and respond to the antigen, and act as mediators of cellular and humoral immune responses (Abbas et al., 2010). Banana midrib extract may have the specific immunostimulatory role that can enhance lymphocyte count as previously reported for Lawsonia inermis and Echinacea purpurea (Aly et al., 2008; Soltanian \& Fereidouni, 2016). Monocyte plays an important role in the defense system of the fish body. Monocytes transform into macrophages and may involve phagocytosis and the killing of pathogens upon the first recognition and subsequent infections (Sivagurunathan et al., 2011). This means that monocytes are just found when there is an agent attacking the host. This might be a reason underlying the presence of monocytes after an infection. Neutrophils are the first cells to respond to infection within $24 \mathrm{~h}$ and their levels increase during bacterial infection to phagocytes (Secombes, 1996). The increase in monocytes and neutrophils in banana midrib extracttreated fish could be attributed to the enhancement of nonspecific immune response. Simultaneously, higher lymphocyte percentages might indicate a specific immune induction (Soltanian \& Fereidouni, 2016). There were significant effects of banana midrib extract diet on neutrophils percentages of giant gourami, particularly in curative treatment during the early period of bacterial infection. It indicated an improvement in the activity of phagocytic cells to phagocyte foreign particles, so that the bacterial infection does not create a worse condition for the host. Thus, banana midrib extract is more effective as a curative agent as indicated by a higher survival of giant gourami than fish on other treatments. The effects of the application of herbal plants to increase the levels of monocytes and granulocytes were also reported by Nugroho et al. (2017), who found significant increases in the number of monocytes and granulocytes in fish immersed with Terminalia catappa L. extract during the period after $A$. hydrophila infection.

\section{Conclusion}

In conclusion, supplementation of banana midrib extract reduced the infection rate of MAS and induced the immune responses of giant gourami. Banana midrib extract is highly effective as a curative agent of MAS, resulting in $100 \%$ survival of giant gourami.

\section{Ethical Statement}

All experiments in this study associated with fish complied with animal welfare and were handled under Indonesia accreditation SNI 01-6485.3-2000 (National Standardization Agency of Indonesia, 2000). All listed authors declare that the study was conducted in an ethical, professional, and responsible manner. 


\section{Funding Information}

Not applicable.

\section{Author Contribution}

Dinamella Wahjuningrum and Widanarni designed the initial concepts of the study, supervised the research, and reviewed the manuscript. Ike Dewi Nur Fitrianingrum performed the experiment, worked on data analysis, and wrote the original draft of the manuscript. Diah Ayu Satyari Utami worked on data interpretation, revised, reviewed, and validated the manuscript. All authors contributed to the writing of the article.

\section{Conflict of Interest}

The authors declare that there is no known competing financial or non-financial, professional, or personal conflicts that could have appeared to influence the work reported in this article.

\section{Acknowledgements}

Not applicable.

\section{References}

Abbas, A.K., Lichtman, A.H., \& Pillai, S. (2010). Cellular and molecular immunology. Saunders Elsevier.

Abolghait, S.K., Fathi, A.G., Youssef, F.M., \& Algammal, A.M. (2020). Methicilin-resistant Staphylococcus aureus (MRSA) isolated from chicken meat and giblets often produces staphylococcal enterotoxin B (SEB) in nonrefrigerated raw chicken livers. International Journal of Food Microbiology, 328, 108669.

https://doi.org/10.1016/j.ijfoodmicro.2020.108669

Abouelmaatti,R.R., Algammal, A.M., Xiaokun, L., Ma, J., Abdelnaby, E.A., \& Elfeil W.M.K. (2013). Cloning and analysis of the Nile tilapia Toll-like receptors type-3 mRNA. Central European Journal of Immunology, 38(3), 277-282. https://doi.org/10.5114/ceji.2013.37740

Algammal, A.M., El-Kholy, A.W., Riad, E.M., Mohamed, H.E., Elhaig, M.M., Al Yousef, S.A., Hozzein, W.N., \& Ghobashy, M.O.I. (2020a). Genes encoding the virulence and the antimicrobial resistance in enterotoxigenic and shigatoxigenic $E$. coli isolated from diarrheic calves. Toxins, 12(6), 383. https://doi.org/10.3390/toxins12060383

Algammal, M.A., El-Sayed, M.E., Youssef, F.M., Saad, S.A., Elhaig, M.M., Batiha, G.E., Hozzein, W.N., \& Ghobashy, M.O.I. (2020b). Prevalence, the antibiogram and the frequency of virulence genes of the most predominant bacterial pathogens incriminated in calf pneumonia. $A M B$ Express, 10, 99. https://doi.org/10.1186/s13568020-01037-z

Algammal, A.M., Enany, M.E., El-Tarabili, R.M., Ghobashy, M.O.I, \& Helmy, Y.A. (2020c). Prevalence, antimicrobial resistance profiles, virulence and enterotoxinsdeterminant genes of MRSA isolated from subclinical bovine mastitis in Egypt. Pathogens, 9, 362. https://doi.org/10.3390/pathogens9050362
Algammal, A.M., Mabrok, M., Sivaramasamy, E., Youssef, F.M., Atwa, M.H., El-kholy A.W., Hetta, H.F., \& Hozzein W.N. (2020d). Emerging MDR-Pseudomonas aeruginosa in fish commonly harbor oprL and toxA virulence genes and bla $a_{\mathrm{TEM}}, b_{\text {b }} a_{\mathrm{CTX}-\mathrm{M}}$, and tetA antibiotic-resistance genes. Scientific Reports, 10, 15961. https://doi.org/10.1038/s41598-020-72264-4

Algammal, A.M., Mohamed, M.F., Tawfiek, B.A., Hozzein W.N., El Kazzaz, W.M., \& Mabrok, M. (2020e). Molecular typing, antibiogram and PCR-RFLP based detection of Aeromonas hydrophila complex isolated from Oreochromis niloticus. Pathogens, 9, 237. https://doi.org/ 10.3390/pathogens9030238

Aly, S.M., Mohammed, M.F., \& John, G. (2008). Echinacea as immunostimulatory agent in Nile tilapia (Oreochromis niloticus) via earthen pond experiment. In $\mathrm{H}$. Elghobashy, K. Fitzsimmons, \& A.S. Diab (Eds.), $8^{\text {th }}$ International Symposium on Tilapia in Aquaculture. 12-14 October 2008. Cairo, Egypt. pp. 1033-1041.

American Public Health Association (APHA). (1995). Standard methods for examination of water and wastewater. American Public Health Association.

Anderson, D.P., \& Siwicki, A.K. (1995). Basic haematology and serology for fish health programs. In M. Shariff, J.R. Arthur, \& R.P. Subasinghe, Diseases in Asian Aquaculture II. Fish Health Section, Asian Fisheries Society.

Angka, S.L. (2005). Study of motile aeromonad septicemia (MAS) in walking catfish (Clarias sp.): Pathology, preventive and curative using phytopharmaca. PhD Thesis. IPB University (in Indonesian).

Apriasari, M.L., Iskandar, \& Suhartono E. (2014). Bioactive compound and antioxiandt activity of methanol extract mauli bananas (Musa sp.) stem. International Journal of Bioscience, Biochemistry and Bioinformatics, 4(2), 110115. https://doi.org/ 10.7763/IJBBB.2014.V4.321

Asgary, S., Naderi, G.H., \& Askari, N. (2005). Protective effect of flavonoids against red blood cell hemolysis by free radicals. Experimental \& Clinical Cardiology, 10(2), 8890.

Azrita, \& Syandri, H. (2015). Morphological character among five strains of giant gourami, Osphronemus gouramy Lacepede, 1801 (Actinopterygii: Perciformes: Osphronemidae) using a truss morphometric system. International Journal of Fisheries and Aquatic Studies, 2(6), 344-350.

Baba, E., Acar, Ü. Öntaş, C, Kesbiç, O.S., \& Yilmaz, S. (2016). The use of Avena sativa extract against Aeromonas hydrophila and its effect on growth performance, hematological and immunological parameters in common carp (Cyprinus carpio). Italian Journal of Animal Science, 15(2), 325-333. https://doi.org/10.1080/1828051X.2016.1185977

Bilen, S., Ünal, S., \& Güvensoy, H. (2016). Effects of oyster mushroom (Pleurotus ostreatus) and nettle (Urtica dioica) methanolic extracts on immune responses and resistance to Aeromonas hydrophila in rainbow trout (Oncorhynchus mykiss). Aquaculture, 454, 90-94. https://doi.org/10.1016/j.aquaculture.2015.12.010

Blaxhall, P.C., \& Daisley, K.W. (1973). Routine haematological methods for use with fish blood. Journal of Fish Biology, 5(6), 771-781. https://doi.org/10.1111/j.1095-8649.1973.tb04510.x

Callewaert, L., \& Michiels, C.W. (2010). Lysozymes in the animal kingdom. Journal of Biosciences, 35, 127-160. https://doi.org/10.1007/s12038-010-0015-5 
Christybapita, D., Divyagnaneswari, M., Michael, R.D. (2007). Oral administration of Eclipta alba leaf aqueous extract enhances the non-spesific immune responses and disease resistance of Orechromis mossambicus. Fish \& Shellfish Immunology, 23(4), 840-852.

https://doi.org/10.1016/j.fsi.2007.03.010

Citarasu, T. (2010). Herbal biomedicines: a new opportunity for aquaculture industry. Aquacuture International, 18, 403-414. https://doi.org/10.1007/s10499-009-9253-7

Clinical and Laboratory Standards Institute (CLSI). (2018). Performance standards for antimicrobial disk susceptibility tests. $13^{\text {th }}$ edition. CLSI standard MO2. Clinical and Laboratory Standards Institute.

Devi, K.N., Dhayanithi, N.B., Kumar, T.T.A., Balasundaram, C., \& Harikrishnan, R. (2016). In vitro and in vivo efficacy of partially purified herbal extracts against bacterial fish pathogens. Aquaculture, 458, 121-133.

https://doi.org/10.1016/j.aquaculture.2016.02.035

Donta, S.T., \& Haddow, A.D. (1978). Cytotoxic activity of Aeromonas hydrophila. Infection and Immunity, 21(3), 989-993. https://doi.org/10.1128/iai.21.3.989-993.1978

El-Sayed, M.E., Algammal, A.M., Abouel-Atta, M.E., Mabrok, M., \& Emam, A.M. (2019). Pathogenicity, genetic typing, and antibiotic sensitivity of Vibrio alginolyticus isolated from Oreochromis niloticus and Tilapia zillii. Revue de Médecine Vétérinaire, 170(4-6), 80-86.

Enany, M.E., Algammal, A.M., Shagar, G.I., Hanora, A.M., Elfeil, W.K., \& Elshaffy, N.M. (2018). Molecular typing and evaluation of Sidr honey inhibitory effect on virulence genes of MRSA strains isolated from catfish in Egypt. Pakistan Journal of Pharmaceutical Sciences, 31(5), 1865-1870.

Fajriyani, A., Hastuti, S., Sarjito. (2017). The effect of ginger powder in diets on blood profile, growth and survival rate of catfish (Pangasius sp.). Journal of Aquaculture Management and Technology, 6(4), 39-48 (in Indonesian).

Febram, B., Wientarsih, I., Pontjo, B. (2010). Activity of Ambon banana (Musa paradisiaca var. sapientum) stem extract in ointment formulation on the wound healing process of mice skin (Mus musculus albinus). Journal of Traditional Medicine, 15(3), 121-137 (in Indonesian). https://doi.org/10.22146/tradmedj.8136

Fitrianingrum, I.D.N. (2014). Effectiveness of immersion treatment on giant goramy fry Osphronemus goramy with white banana stem Musa paradisiaca extract in controlling infection of Aeromonas hydrophila. Undergraduate Thesis. IPB University (in Indonesian).

Fitrianingrum, I.D.N. (2015). Effectivity of banana midrib extract as antibacterial and immune-stimulant for giant gourami infected with Aeromonas hydrophila. Master Thesis. IPB University (in Indonesian).

Giri, S.S., Jun, J.W., Sukumaran, V., \& Park, S.C. (2016). Dietary administration of banana (Musa acuminata) peel flour affects the growth, antioxidant status, cytokine responses, and disease susceptibility of Rohu, Labeo rohita. Journal of Immunology Research, 2016, 4086591. https://doi.org/10.1155/2016/4086591

Galindo-Villegas, J., \& Hosokawa, H. (2004). Immunostimulants: towards temporary prevention of diseases in marine fish. In L.E. Cruz Suárez, D. Ricque Marie, M.G. Nieto López, D. Villareal, U. Scholz, \& M. y González (Eds.), Avances en Nutrición Acuícola VII. Memorias del VII Simposium Internacional de Nutrición
Acuícola. 16-19 November 2004. Hermosilla, Sonora, Mexico.

Gardenia, L., Sukenda, Zairin Junior, M., Lusiastuti, A.M., \& Alimuddin. (2020). Development of primary cell culture from spleen of giant gourami Osphronemus goramy for propagation of giant gourami iridovirus (GGIV). Journal of Fish Diseases, 43(8), 829-838. https://doi.org/10.1111/jfd.13155

Hardi, E.H., Nugroho, R.A., Kusuma, I.W., Suwinarti, W., Sudaryono, A., \& Rostika, R. (2019). Borneo herbal plant extracts as a natural medication for prophylaxis and treatment of Aeromonas hydrophila and Pseudomonas fluorescens infection in tilapia (Oreochromis niloticus). F1000Research, 7, 1847. https://doi.org/10.12688/f1000research.16902.2

Harikrishnan, R., Balasundaram, C., \& Heo, M.S. (2010). Herbal supplementation diets on hematology and innate immunity in goldfish against Aeromonas hydrophila. Fish \& Shellfish Immunology, 28(2), 354-361. https://doi.org/10.1016/j.fsi.2009.11.013

Harper, C., \& Wolf, J.C. (2009). Morphologic effects of the stress response in fish. Ilar Journal, 50(4), 387-396. https://doi.org/10.1093/ilar.50.4.387

Haryani, A., Grandiosa, R., Buwono, I.D., \& Santika, A. (2012). Study of the effectiveness of papaya (Carica papaya) leaf for the treatment of Aeromonas hydrophila infection on goldfish (Carassius auratus). Jurnal Perikanan dan Kelautan, 3(3), 213-220 (in Indonesian).

Holt, J.G., Krieg, N.R., Sneath P.H.A., Staley, J.T., \& Williams, S.T. (1994). Bergey's manual of determinative bacteriology, ninth edition. Lippincott Williams \& Wilkins.

Hudzicki, J. (2009). Kirby-Bauer disk diffusion susceptibility test protocol. American Society for Microbiology.

Ibrahem, M.D., Mostafa, M.M., Arab, R.M.H., \& Rezk, M.A. (2008). Prevalence of Aeromonas hydrophila infection in wild and cultured Tilapia nilotica (O. niloticus) in Egypt. In H. Elghobashy, K. Fitzsimmons, \& A.S. Diab (Eds.), $8^{\text {th }}$ International Symposium on Tilapia in Aquaculture. 1214 October 2008. Cairo, Egypt. pp. 1257-2171.

Ielpo, M.T.L., Basile, A., Miranda, R., Moscatiello, V., Nappo, C., Sorbo, S., Ricciardi M.M., Ricciardi, L., \& Vuotto, M.L. (2000). Immunopharmacological properties of flavonoids. Fitoterapia, 71(1), S101-S109. https://doi.org/10.1016/S0367-326X(00)00184-2

Immanuel, G., Vincybai, V.C., Sivaram, V., \& Marian, M.P. (2004). Effect of butanolic extracts from terrestrial herbs and seaweeds on the survival, growth and pathogen (Vibrio parahaemolyticus) load on shirmp Penaeus indicus juveniles. Aquaculture, 236(1-4), 53-65. https://doi.org/10.1016/j.aquaculture.2003.11.033

Ismail, N.E.D.A., Atta, N.S., \& Abd E Aziz, M.A. (2010). Oral vaccination of Nile tilapia (Oreochromis niloticus) against motile Aeromonas septicaemia. Nature and Science, $8(2), 21-26$.

Istikhanah, Sarjito, \& Prayitno, S.B. (2014). The effect of dyeing Piper betle linn extract to mortality and histopathology kidney of carp (Cyprinus carpio) which it was infected by Aeromonas hydrophila bacteria. Journal of Aquaculture Management and Technology, 3(3), 51-57 (in Indonesian).

Janda, J.M., \& Abbott, S.L. (2010). The genus Aeromonas: Taxonomy, pathogenicity, and infection. Clinical Microbiology Reviews, 23(1), 35-73. https://doi.org/ 10.1128/CMR.00039-09 
Kahuripan, A., Andrajati, R., \& Syafridani, T. (2009). Analysis of the administration of antibiotics based on the results of sensitivity test to the achievement of clinical outcome of the diabetic ulcer patients in RSUD dr. H. Abdul Moeloek Lampung. Majalah Ilmu Kefarmasian, 6(2), 75-87 (in Indonesian). https://doi.org/10.7454/psr.v6i2.3437

Karimi, S.H., Kochinian, P., \& Salati, A.P. (2013). The effect of sexuality on some haematological parameters of the yellowfin seabream, Acanthopagrus latus in Persian Gulf. Iranian Journal of Veterinary Research, 14(1), 6568. https://doi.org/ 10.22099/ijvr.2013.1392

Kitagawa, S., Fujisawa, H., \& Sakurai, H. (1992). Scavenging effects of dihydric and polyhydric phenols on superoxide anion radicals, studied by electron spin resonance spectrometry. Chemical and Pharmaceutical Bulletin, 40(2), 304-307. https://doi.org/10.1248/cpb.40.304

Kitao, T., Ruangpan, L., \& Fukudome, M. (1989). Isolation and classification of a Nocardia species from diseased giant gourami Osphronemus goramy. Journal of Aquatic Animal Health, 1(2), 154-162.

https://doi.org/10.1577/1548-

8667(1989)001<0154:IACOAN>2.3.CO;2

Koesharyani, I., \& Gardenia, L. (2013). New megalocytivirus infected to the cultured fresh water giant gourami, Osphronemus gouramy Lac. in Indonesia. Indonesian Aquaculture Journal, 8(1), 93-99.

http://dx.doi.org/10.15578/iaj.8.1.2013.93-99

Koeypudsa, W., \& Jongjareanjai, M. (2010). Effect of water temperature on hematology and virulence of Aeromonas hydrophila in hybrid catfish (Clarias gariepinus Burchell $\times$ C. macrocephalus Gunther). Thai Journal of Veterinary Medicine, 40(2), 179-186.

Kristanto, A.H., Slembrouck, J., Subagja, J., Pouil, S., Arifin, O.Z., Prakoso, V.A., \& Legendre, M. (2020). Survey on egg and fry production of giant gourami (Osphronemus goramy): Current rearing practices and recommendations for future research. Journal of the World Aquaculture Society, 51(1), 119-138.

https://doi.org/10.1111/jwas.12647

Kumar, S., \& Pandey, A.K. (2013). Chemistry and biological activities of flavonoids: an overview. The Scientific World Journal, 2013, 162750.

https://doi.org/10.1155/2013/162750

Logambal, S.M., Venkatalakshmi, S., \& Micheal, R.D. (2000). Immunostimulatory effect of leaf extract of Ocimum sanctum Linn. in Oreochromis mossambicus (Peters). Hydrobiologia, 430, 113-120.

https://doi.org/10.1023/A:1004029332114

Lusiastuti, A.M., Supriyadi, H., Aryati, Y., Mufidah, T., Gardenia, L., \& Sumiati, T. (2008). Case study: streptococcosis in gurami (Osphronemus gouramy) caused by Streptococcus iniae and Streptococcus agalactiae. Proceeding of Aquaculture Technology Exhibition Seminar. 02-03 May 2008, Manado, Indonesia. pp. 335340 (in Indonesia).

Mangunwardoyo, W., Ismayasari, R., \& Riani, E. (2010). Pathogenicity and virulency of Aeromonas hydrophila stainer on nila fish (Oreochromis niloticus Lin.) using Koch postulate. Jurnal Riset Akuakultur, 5(2), 245-255. http://dx.doi.org/10.15578/jra.5.2.2010.145-255

Miean, K.H., \& Mohamed, S. (2001). Flavonoid (myricetin, quercetin, kaempferol, luteolin, and apigenin) content of edible tropical plants. Journal of Agricultural and Food Chemistry, 49(6), 3106-3112. https://doi.org/10.1021/jf000892m
Minaka, A., Sarjito, \& Hastuti, S. (2012). Identification of causing agents and blood profile of giant gourami (Osphronemus gouramy) attacked by bacterial diseases. Journal of Aquaculture Management and Technology, 1(1), 249-263 (in Indonesia).

National Standardization Agency of Indonesia. (2000). SNI 016485.3-2000. Production of gourami (Osphronemus goramy, Lac) juvenile stocking juvenile class. National Standardization Agency of Indonesia.

Nugroho, R.A., Manurung, H., Nur, F.M., \& Prahastika, W. (2017). Terminalia catappa L. extract improves survival, hematological profile and resistance to Aeromonas hydrophila in Betta sp. Archives of Polish Fisheries, 25, 103-115. https://doi.org/ 10.1515/aopf-2017-0010

Osman, A.G.M., Koutb, M., \& Sayed, A. (2010). Use of hematological parameters to assess the efficiency of quince (Cydonia oblonga Miller) leaf extract in alleviaton of the effect of ultraviolet - A radiation on African catfish Clarias gariepinus (Burchell, 1822). Journal of Photochemistry and Photobiology B: Biology, 99(1), 1-8. https://doi.org/10.1016/j.jphotobiol.2010.01.002

Pattah, H., Wahjuningrum, D., Yuhana, M., \& Widanarni. (2020). Control of Vibrio alginolyticus in Asian sea bass Lates calcalifer using Ambon banana plant powder Musa paradisiacal through the feed. Indonesian Aquaculture Journal, 15(2), 85-91.

http://dx.doi.org/10.15578/iaj.15.2.2020.85-91

Purwaningsih, U., \& Taukhid. (2010). Diagnosis of mycobacteriosis, Mycobacterium fortuitum on giant gourami (Osphronemus gouramy) with polymerase chain reaction (PCR) technique. Proceeding of Aquaculture Technology Inovation Forum. pp. 969-975 (in Indonesia).

Roghini, R., \& Vijayalakshmi, K. (2018). Phytochemical screening, quantitative analysis of flavonoids and minerals in ethanolic extract of Citrus paradisi. International Journal of Pharmaceutical Sciences and Research, 9(11), 4859-4864.

https://doi.org/10.13040/IJPSR.0975-8232.9(11).485964

Şahan, A., Özütok, S., \& Kurutaş, E.B. (2016). Determination of some hematological parameters and antioxidant capacity in Nile tilapia (Oreochromis niloticus Linnaeus, 1758) fed ginger (Zingiber officinale Roscoe) to Aeromonas hydrophila. Turkish Journal of Fisheries and Aquatic Sciences, 16: 197-204. https://doi.org/10.4194/1303-2712-v16_1_20

Sakunphueak, A., \& Panichayupakaranant, P. (2010). Simultaneous determination of three naphthoquinones in the leaves of Impatiens balsamina L. by reversedphase high-performance liquid chromatography. Phytochemical Analysis, 21(5), 444-450. https://doi.org/10.1002/pca.1216

Secombes, C.J. (1990). Isolation of salmonid macrophages and analysis of their killing activity. In J.S. Stolen, T.C. Fletche, D.P. Anderson, B.S. Robertson, \& W.B. van Muiswinkel (Eds.), Techniques in fish immunology, 1. SOS Publication.

Secombes, C.J. (1996). The nonspecific immune system: cellular defenses. In G. Iwama, \& T. Nakanishi (Eds.), The fish immune system: organism, pathogen and environment. Academic Press.

Setijaningsih, L., Arifin, O.Z., \& Gustiano, R. (2007). Characterization of three strains of giant gouramy (Osphronemus gouramy Lac.) based on truss 
morphometries method. Jurnal Iktiologi Indonesia, 7(1), 23-30 (in Indonesian). https://doi.org/10.32491/jii.v7i1.220

Sivagurunathan, A., Meera, K.A., \& Innocent, B.X. (2011). Investigation of immunostimulant potential of Zingiber officinale \& Curcuma longa in Cirrhinus mrigala exposed to Pseudomonas aeruginosa - Haematological assessment. International Journal of Research in Ayurveda \& Pharmacy, 2(3), 899-904.

Slembrouck, J., Arifin, O.Z., Pouil, S., Subagja, J., Yani, A., Kristanto, A.H., \& Legendre, M. (2019). Gender identification in farmed giant gourami (Osphronemus goramy): A methodology for better broodstock management. Aquaculture, 498, 388-395. https://doi.org/10.1016/j.aquaculture.2018.08.056

Sofowora, A. (1993). Medicinal plants and traditional medicinal in Africa. $2^{\text {nd }}$ edition. Spectrum Books Ltd.

Soltani, M., \& Pourgholam, R. (2007). Lysozyme activity of grass carp (Ctenopharingodon Idella) following exposure to sublethal concentrations of organophosphate, diazinon. Journal of Veterinary Research, 62(2), 50-52.

Soltanian, S., \& Fereidouni, M.S. (2016). Effect of henna (Lawsonia inermis) extract on the immunity and survival of common carp, Cyprinus carpio infected with Aeromonas hydrophila. International Aquatic Research, 8, 247-261. https://doi.org/10.1007/s40071-016-0141-2

Stratev, D., \& Odeyemi, O.A. (2016). Antimicrobial resistance of Aeromonas hydrophila isolated from different food resources: A mini-review. Journal of Infection and Public Health, 9(5), 535-544.

https://doi.org/10.1016/j.jiph.2015.10.006

Suely, A., Zabed, H., Ahmed, A.B.A., Mohamad, J., Nasirudin, M., Sahu, J.N., \& Ganesan, P. (2016). Toxicological and hematological effect of Terminalia arjuna bark extract on a freshwater catfish, Heteropneustes fossilis. Fish Physiology and Biochemistry, 42, 431-444. https://doi.org/10.1007/s10695-015-0149-3

Sukenda, Jamal, L., Wahjuningrum, D., \& Hasan, A. (2008). Use of chitosan to prevent Aeromonas hydrophila infection on catfish Clarias sp. Jurnal Akuakultur Indonesia, 7(2), 159-169 (in Indonesian). https://doi.org/10.19027/jai.7.159-169

Sukenda, Gardenia, L., Zairin Jr, M., Lusiastuti, A. M., \& Alimuddin. (2020). Identification of giant gourami iridovirus (GGIV): a new infectious spleen and kidney necrosis virus (ISKNV) from natural outbreak in cultured Osphronemus goramy. Aquaculture International, 28, 1069-1082. https://doi.org/10.1007/s10499-020-005134

Trease, G.E., \& Evans, W.C. (2002). Pharmacognosy. 15 edition. Saunders Publishers.

Venkatesh, V.K., Krishnappa, P., Kumar, S., Rajanna, S., Haris, M., \& Keriyappa, V. (2014). Pharmacological properties of corm ethanol extract of Musa paradisiaca (L.) cv. Puttabale. World Journal of Pharmacy and Pharmaceutical Sciences, 3(5), 1362-1383.

Wahjuningrum, D., Solikhah, E.H., Budiardi, T., \& Setiawati, M. (2010). Infection control of Aeromonas hydrophila in catfish (Clarias sp.) using mixture of meniran Phyllanthus niruri and garlic Allium sativum in feed. Jurnal Akuakultur Indonesia, 9(2), 93-103 (in Indonesian). https://doi.org/10.19027/jai.9.93-103

Wahjuningrum, D., Tarman, K., Faradisa, N., Frasetia, A.P., \& Rudi, M. (2020). Utilization of Mycelium sterilium KT31 metabolites with diet for controlling Aeromonas hydrophila infection on catfish Clarias gariepinus. IOP Conference Series: Earth and Environmental Science, 414, 012029. https://doi.org/10.1088/1755-1315/414/1/012029

Welcomme, R.L. (1988). International introductions of inland aquatic species, FAO fisheries technical paper 294. Food and Agriculture Organization.

Yardimci, B., \& Aydin, Y. (2011). Pathological findings of experimental Aeromonas hydrophila infection in Nile tilapia (Oreochromis niloticus). Ankara Üniversitesi Veteriner Fakültesi Dergisi, 58(1), 47-54. https://doi.org/10.1501/Vetfak_0000002448 